\title{
ARTICLES
}

\section{NURSES' KNOWLEDGE AND ATTITUDE ON PRACTICE OF ARTIFICIAL AIRWAY SUCTIONING}

\author{
Ms. Smitha Sunny*| Dr. S. Rajina Rani**
}

*Research Scholar, Himalayan University, Itanagar in Arunachal Pradesh, India. **Research Supervisor, Himalayan University, Itanagar in Arunachal Pradesh, India.

ABSTRACT:

DOI: http://doi.org/10.47211/trr.2021.v07i01.005

Artificial airway suctioning is one of the key nursing skills that nurses should acquire during student period and maintains during their professional life. The current study is mainly intended to assess the knowledge and attitude among graduate nurses, Kerala. A quantitative descriptive approach was used as methodology with convenient sampling technique and data were collected using electronic forms. Data were analyzed using descriptive and inferential statistics. There is a mild correlation between knowledge and attitude score $(r=0.199)$ and significant association can be traced with the area of experience and knowledge (chi-square $=0.037$ ) and the training undergone related to suctioning and attitude on practice related to suctioning (chi-square $=0.000674$ ).

Key words: Knowledge, Attitude, Artificial airway suctioning, Graduate Nurses.

\section{ABOUT AUTHORS:}

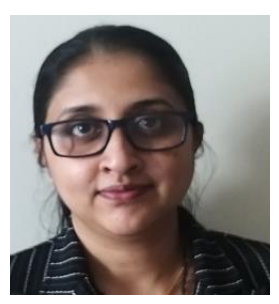

Author Ms. Smitha Sunny is a Research Scholar in Himalayan University, Itanagar in Arunachal Pradesh, India. She has attended various Seminars and conferences.

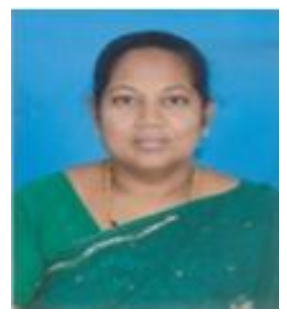

Author Dr. S. Rajina Rani is an active researcher with many publications in her name. She has attended and organised various National and International conferences and has given extensive lectures. At present she is research supervisor, Himalayan University, Itanagar in Arunachal Pradesh, India. 


\section{ARTICLES}

\section{INTRODUCTION:}

The COVID 19 pandemic aroused the healthcare workers to be equipped in managing patients with artificial airways and the most important function of nurses is to maintain artificial airway through suctioning.

Artificial airway suctioning which includes Endotracheal and Tracheostomy suctioning is mainly intended to remove secretions from the pulmonary system. The aim is to keep airway open and thereby improving oxygenation and prevent atelectasis. It is very important that nurses should have adequate knowledge pertaining to suctioning with correct technique and thereby decreasing complications such as bleeding, infections, hypoxia, bronchoconstriction, atelectasis, increased intracranial pressure, cardiac arrest, and sudden death.

Evidenced based practice (EBP) is a process updating nursing knowledge and is required in clinical decision making, which needs to be inculcated from the student period with a view to focus on future nurses (Pashaeypoor, S., 2017). It is the need of the hour that Evidence-based teaching should be moved from classrooms to clinical practice to achieve improvement in substantial outcomes. The nurses should upgrade their knowledge related to suctioning. Even though EBP guidelines are available, it is mandatory that proper monitoring related to practice to ensure the safety of the patient. In a study conducted in China, considerable evidenced based practice gaps have been observed in Chinese intensive care practices(Chen, W., Hu, S., Liu, X., Wang, N., Zhao, J., Liu, P., \& Hu, J. (2021). In 2010 American Association of Respiratory Care (AARC) set guidelines for artificial airway suctioning. Some steps in artificial airway suctioning including auscultation of chest, post-suctioning assessment, wearing apron, maintaining suction pressure between 80 and $150 \mathrm{mmHg}$, reassuring the patient after suctioning, hand washing post-suctioning, explaining the procedure to the patient, length of time applied to suction the airway, hand washing prior to suctioning, and maintaining the suction catheter's sterility are ignored by more than $50 \%$ of critical care nurses in a study conducted in India (Varghese, S. T., \& Moly, K. T. (2016).

Irrespective of the area of experience, the pandemic demands nurses forcefully to take care of critical care patients, hence the investigator tried to identify the knowledge and attitude of the nurses who are graduated from Kerala from 2015 onwards. The nurse leaders need to revise the educational system by including evidenced based practices in theoretical and clinical aspects for the better-quality patient care. The investigator felt that adequate knowledge regarding artificial airway suctioning is the need of the hour as huge number nurses are dedicated them to care COVID 19 affected patients.

\section{OBJECTIVES:}

1. To assess the knowledge and attitude on practice of artificial airway suctioning among nurses

2. To find out association of knowledge and attitude among nurses with the selected demographic variables METHODS AND MATERIAL:

Quantitative approach with descriptive survey method was used to collect data. The study population was registered nurses who are graduated from different institutions from a specific district in Kerala and currently working in different hospitals. 122 staff nurses who have completed their degree in nursing from 2015 randomly selected by convenient sampling technique. The data were collected individually through electronic forms from the nurses who are working in different parts of the world.

Self-administered questionnaire was used to assess the knowledge and attitude of nurses regarding artificial airway suctioning, which is prepared based on the literature review and validated by 8 experts in the nursing field. The data was collected after obtaining individual consent from the sample. Data were analyzed using descriptive and inferential statistics.

\section{RESULTS:}

In the present study 122 female nurses participated with the age less than 30 years. All of them are graduate nurses passed out between the years of 2015 and 2019. The study participants included 42 nurses from ICU and 80 from Medical-Surgical wards, Endoscopy and Dialysis units. 96 nurses were having experience related to suctioning during student period and 94 were having experience during staff period. 84 nurses undergone training related to suctioning and shows association with the attitude at 0.05 significance level $\left(p=*^{*} 0.000674\right)$ in Table 3 . The knowledge level of the nurses is also associated with the working area at 0.05 significance level $(p=* 0.030714)$. Table 5 shows mild correlation between knowledge and attitude. 


\section{ARTICLES}

Table .1 Distribution of knowledge score on practice of artificial airway suctioning

\begin{tabular}{|c|c|c|c|}
\hline S. No & Knowledge questionnaire & Correct answer & Category \\
\hline \multicolumn{4}{|c|}{ Score category: High - 76-100\%, Average $-50-75 \%$ and Low $<50 \%$} \\
\hline 1 & How often ET/Tracheostomy suctioning is required? & $32(26.2 \%)$ & Low \\
\hline 2 & $\begin{array}{l}\text { What is the size of the suction catheter that can use for suctioning the } \\
\text { tracheostomy tube of size } 8 \text { ? }\end{array}$ & $54(44.3 \%)$ & Low \\
\hline 3 & $\begin{array}{l}\text { Which is the best method to loosen the secretions of a patient with } \\
\text { artificial airway prior suctioning? }\end{array}$ & $54(44.3 \%)$ & Low \\
\hline 4 & $\begin{array}{l}\text { Which of the following a nurse should initiate to prevent hypoxemia } \\
\text { when suctioning a patient through artificial airways? }\end{array}$ & $54(44.3 \%)$ & Low \\
\hline 5 & What is the recommended duration of a suctioning event? & $58(47.5 \%)$ & Low \\
\hline 6 & What is the negative pressure that can be applied while suctioning? & $24(19.7 \%)$ & Low \\
\hline 7 & $\begin{array}{l}\text { How far down a tracheal- tube should the suction catheter be passed } \\
\text { that minimizes patient complications of tracheal mucosal damage, } \\
\text { patient discomfort and autonomic effects? }\end{array}$ & $54(44.3 \%)$ & Low \\
\hline 8 & $\begin{array}{l}\text { Which is the best position to provide endotracheal suctioning to } \\
\text { prevent ventilator- associated - pneumonia unless medically } \\
\text { contraindicated? }\end{array}$ & $78(63.9 \%)$ & Average \\
\hline 9 & $\begin{array}{l}\text { Which suction technique decreases the aerosolization of tracheal } \\
\text { secretions during suction induced coughing and reduce hand and } \\
\text { equipment cross-contamination? }\end{array}$ & $96(78.7 \%)$ & High \\
\hline 10 & An indicator of suctioning is & $62(53.4 \%)$ & Average \\
\hline 11 & $\begin{array}{l}\text { Identify the nerve that can be affected while performing endotracheal } \\
\text { suctioning and can cause bradycardia }\end{array}$ & $54(44.3 \%)$ & Low \\
\hline 12 & $\begin{array}{l}\text { How many suction passes can be done if secretions remain in the } \\
\text { airway and the patient is tolerating the procedure? }\end{array}$ & $66(54.1 \%)$ & Average \\
\hline
\end{tabular}




\section{ARTICLES}

Table 2: Distribution of Attitude score on practice of artificial airway suctioning

\begin{tabular}{|c|c|c|c|c|}
\hline S.No & Attitude questionnaire & Yes & No & Category \\
\hline \multicolumn{5}{|c|}{ Score category: High - 76-100\%, Average $-50-75 \%$ and Low $<50 \%$} \\
\hline 1 & $\begin{array}{l}\text { Do you perform hand hygiene and don PPE for the artificial airway } \\
\text { suctioning? }\end{array}$ & $100(82 \%)$ & $\begin{array}{l}22 \\
(18 \%)\end{array}$ & High \\
\hline 2 & $\begin{array}{l}\text { Do you introduce nurse to the patient and verify correct patient } \\
\text { using two identifiers? }\end{array}$ & $\begin{array}{l}118 \\
(96.7 \%)\end{array}$ & $\begin{array}{l}4 \\
(3.3 \%)\end{array}$ & High \\
\hline 3 & $\begin{array}{l}\text { Do you assess the signs of airway obstruction and breathing } \\
\text { pattern? }\end{array}$ & $\begin{array}{l}118 \\
(96.7 \%)\end{array}$ & $\begin{array}{l}4 \\
(3.3 \%)\end{array}$ & High \\
\hline 4 & $\begin{array}{l}\text { Do you use pain relief medications are not required at all before } \\
\text { suctioning the patient in acute care settings }\end{array}$ & $\begin{array}{l}34 \\
(27.9 \%)\end{array}$ & $\begin{array}{l}88 \\
(72.1 \%)\end{array}$ & Low \\
\hline 5 & $\begin{array}{l}\text { Do you turn on the suction apparatus and set the vacuum } \\
\text { regulator to less than } 150 \mathrm{~mm} \mathrm{Hg} \text { ? }\end{array}$ & $\begin{array}{l}84 \\
(68.9)\end{array}$ & $\begin{array}{l}38 \\
(31.1 \%)\end{array}$ & Average \\
\hline 6 & $\begin{array}{l}\text { It is not required to use sterile gloves always for endotracheal } \\
\text { suctioning. Do you agree? }\end{array}$ & $\begin{array}{l}34 \\
(27.9 \%)\end{array}$ & $\begin{array}{l}88 \\
(72.1 \%)\end{array}$ & Average \\
\hline 7 & $\begin{array}{l}\text { Do you agree to check equipment for proper functioning by } \\
\text { suctioning a small amount of sterile solution from the container? }\end{array}$ & $\begin{array}{l}110 \\
(90.2 \%)\end{array}$ & $\begin{array}{l}12 \\
(9.83 \%)\end{array}$ & High \\
\hline 8 & $\begin{array}{l}\text { Do you administer } 100 \% \text { oxygen to the patient for } 60 \text { seconds } \\
\text { before and after each suction pass? }\end{array}$ & $\begin{array}{l}94 \\
(77 \%)\end{array}$ & $\begin{array}{l}28 \\
(23 \%)\end{array}$ & High \\
\hline 9 & $\begin{array}{l}\text { Do you gently but quickly, insert the catheter with the dominant } \\
\text { hand into the artificial airway with the control vent of suction } \\
\text { open? }\end{array}$ & $\begin{array}{l}104 \\
(85.2 \%)\end{array}$ & $\begin{array}{l}18 \\
(14.8 \%)\end{array}$ & High \\
\hline 10 & $\begin{array}{l}\text { Do not instil } 0.9 \% \text { sodium chloride solution into the artificial } \\
\text { airway before suctioning. Do you agree? }\end{array}$ & $\begin{array}{l}60 \\
(49.2 \%)\end{array}$ & $\begin{array}{l}62 \\
(50.8 \%)\end{array}$ & Low \\
\hline 11 & $\begin{array}{l}\text { Do you rotate the catheter to reposition it away from the side hole } \\
\text { or withdraw it slightly and reinsert it with the next inhalation, if } \\
\text { the catheter does not advance past the end of the ET tube? }\end{array}$ & $\begin{array}{l}78 \\
(63.9 \%)\end{array}$ & $\begin{array}{l}44 \\
(36.1 \%)\end{array}$ & Average \\
\hline 12 & $\begin{array}{l}\text { Do you place the non-dominant thumb over the control vent of } \\
\text { the suction catheter to apply continuous suction? }\end{array}$ & $\begin{array}{l}90 \\
(73.7 \%)\end{array}$ & $\begin{array}{l}32 \\
(26.3 \%)\end{array}$ & Average \\
\hline 13 & $\begin{array}{l}\text { Do you place and maintain the catheter between the dominant } \\
\text { thumb and forefinger while completely withdrawing the catheter } \\
\text { for } 15 \text { seconds or less into the sterile catheter sleeve (closed- } \\
\text { suction technique) or out of the open airway (open-suction } \\
\text { technique)? }\end{array}$ & $\begin{array}{l}96 \\
(78.7 \%)\end{array}$ & $\begin{array}{l}26 \\
(21.3 \%)\end{array}$ & High \\
\hline 14 & $\begin{array}{l}\text { Do you rinse the catheter and connecting tubing with sterile saline } \\
\text { or sterile water until clean? }\end{array}$ & $\begin{array}{l}102 \\
(83.6 \%)\end{array}$ & $\begin{array}{l}20 \\
(16.4 \%)\end{array}$ & High \\
\hline 15 & $\begin{array}{l}\text { Do you remove sterile glove(s) and dispose of catheter after } \\
\text { completion of upper-airway open method suctioning? }\end{array}$ & $\begin{array}{l}106 \\
(86.9 \%)\end{array}$ & $\begin{array}{l}16 \\
(13.1 \%)\end{array}$ & High \\
\hline
\end{tabular}




\section{ARTICLES}

Table 3. Association between Knowledge and selected demographic variables

\begin{tabular}{|c|c|c|c|c|c|}
\hline \multirow[b]{2}{*}{ Variables } & \multicolumn{3}{|c|}{ Knowledge Score } & \multirow[b]{2}{*}{ Chi-square } & \multirow[b]{2}{*}{ p-value } \\
\hline & $<50$ & $50-75$ & $75-100$ & & \\
\hline $\begin{array}{l}\text { Area of experience } \\
\text { ICU } \\
\text { Others }\end{array}$ & $\begin{array}{l}14 \\
46\end{array}$ & $\begin{array}{l}25 \\
32\end{array}$ & $\begin{array}{l}3 \\
2\end{array}$ & 6.96607769 & *0.030714 \\
\hline $\begin{array}{l}\text { Student-experience } \\
\text { No } \\
\text { Yes }\end{array}$ & $\begin{array}{l}10 \\
50\end{array}$ & $\begin{array}{l}16 \\
41\end{array}$ & $\begin{array}{l}0 \\
5\end{array}$ & 3.6787 & 0.158918 \\
\hline $\begin{array}{l}\text { Staff - experience } \\
\text { No } \\
\text { Yes }\end{array}$ & $\begin{array}{l}18 \\
42 \\
\end{array}$ & $\begin{array}{l}10 \\
47 \\
\end{array}$ & $\begin{array}{l}0 \\
5 \\
\end{array}$ & 4.11773583 & 0.127598 \\
\hline $\begin{array}{l}\text { Training done } \\
\text { No } \\
\text { Yes }\end{array}$ & $\begin{array}{l}16 \\
44\end{array}$ & $\begin{array}{l}22 \\
35\end{array}$ & $\begin{array}{l}0 \\
5\end{array}$ & 4.298404 & 0.253977 \\
\hline
\end{tabular}

Table 4. Association between Attitude and selected demographic variables

\begin{tabular}{|c|c|c|c|c|c|}
\hline \multirow{2}{*}{ Variables } & \multicolumn{3}{|c|}{ Attitude Score } & \multirow{2}{*}{ Chi-square } & \multirow{2}{*}{ p-value } \\
\hline & $<50$ & $50-75$ & $75-100$ & & \\
\hline $\begin{array}{l}\text { Area of experience } \\
\text { ICU }\end{array}$ & 2 & 30 & 10 & \multirow[t]{2}{*}{4.57615268} & \multirow[t]{2}{*}{0.101461} \\
\hline Others & 0 & 54 & 26 & & \\
\hline $\begin{array}{l}\text { Student-experience } \\
\text { No }\end{array}$ & 0 & 20 & 6 & \multirow[t]{2}{*}{1.317384} & \multirow[t]{2}{*}{0.517528} \\
\hline Yes & 2 & 64 & 30 & & \\
\hline $\begin{array}{l}\text { Staff - experience } \\
\text { No }\end{array}$ & 0 & 24 & 4 & \multirow[t]{2}{*}{4.95016162} & \multirow[t]{2}{*}{0.105867} \\
\hline Yes & 2 & 60 & 32 & & \\
\hline $\begin{array}{l}\text { Training done } \\
\text { No } \\
\text { Yes }\end{array}$ & $\begin{array}{l}0 \\
2\end{array}$ & $\begin{array}{l}18 \\
66\end{array}$ & $\begin{array}{l}20 \\
16\end{array}$ & 14.6051 & $* 0.000674$ \\
\hline
\end{tabular}

Table 5: Correlation between Knowledge and Attitude score regarding artificial airway suctioning

\begin{tabular}{|c|c|c|c|c|c|}
\hline Variables & No. of items & Mean & $\begin{array}{c}\text { Standard } \\
\text { Deviation }\end{array}$ & Coefficient correlation ' $r$ ' & P value \\
\cline { 1 - 4 } Knowledge & 12 & 5.67 & 2.17970 & 0.199487786 & 0.027600158 \\
\cline { 1 - 4 } Attitude & 15 & 10.278688 & 1.84642 & & \\
\hline
\end{tabular}


Graph 1: Knowledge and Attitude regarding Artificial Airway Suctioning

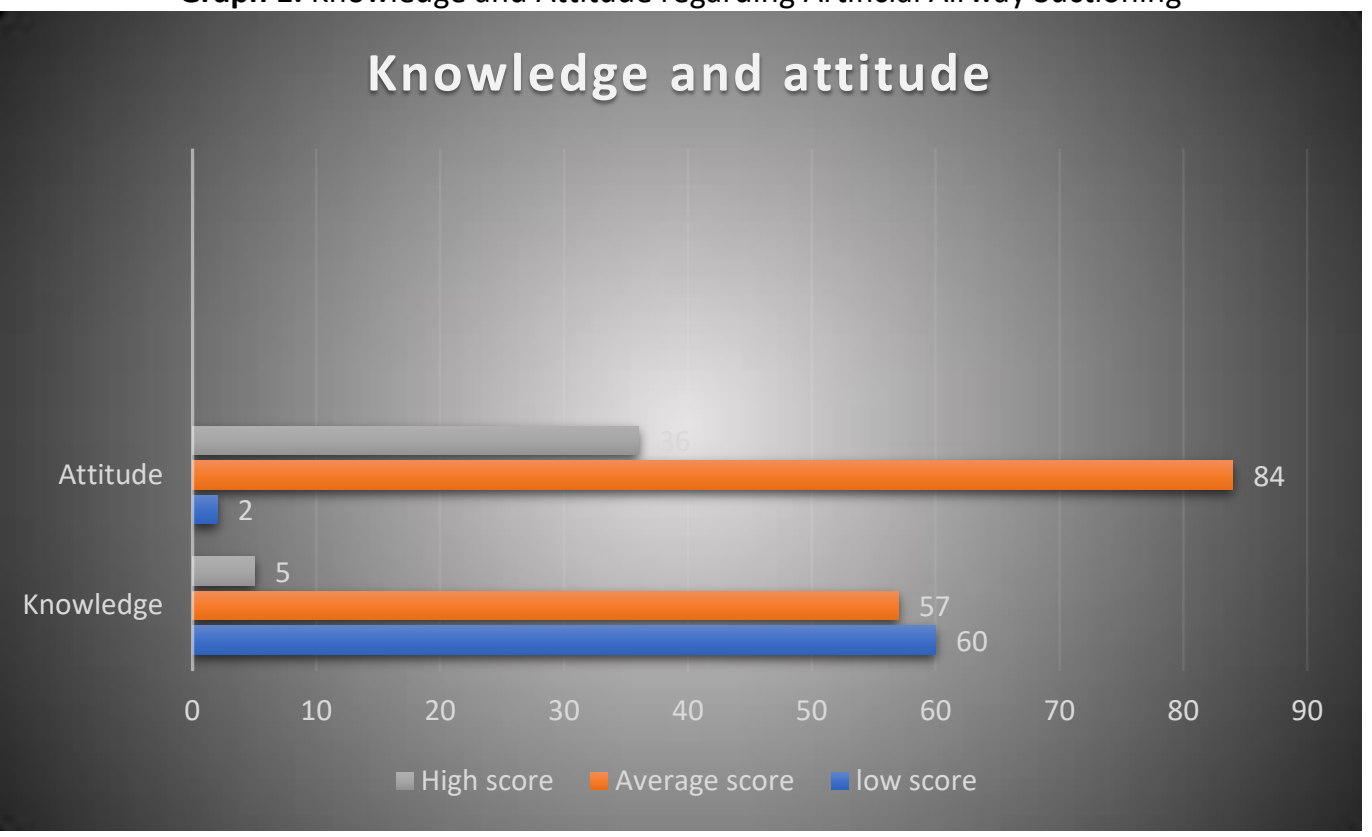

\section{DISCUSSION}

Artificial airway bypasses normal upper airway functions which include humidification, expulsion of secretions, warming of inspired gases and filtration. As a result, there is impaired secretion removal, and the bronchial hygiene is maintained through suctioning. Therefore, nurses must have adequate knowledge and skills to perform the procedure.

Among the study participants $68.9 \%$ were undergone training related to suctioning and shows significant association with the attitude towards suctioning but not with the knowledge. This is like a study conducted in Tanzania with the undesired knowledge level of 80.6\% (Mwakanyanga, E. T., Masika, G. M., \& Tarimo, E. A. (2018). Moreover, $78.7 \%$ of study participants have some sort of experience during their student period. $34.4 \%$ of nurses are having critical care experience and their knowledge level shows significant association with the experience.

\section{Knowledge assessment}

While assessing the knowledge level, the frequency of the suctioning, the size of the suction catheter to be used, the best method to loosen secretion and to prevent hypoxemia, the duration of the suctioning event, the recommended length of the suction catheter to be inserted, the nerve that can be affected and can cause bradycardia, recommended negative pressure for the suctioning are frequently missed by the participants as mentioned in the table 1 and 2 .

The mean score knowledge of the participants is $47.5 \%$ and it clearly indicated that there is gap in acquiring knowledge related to evidenced based practices. Only $26.7 \%$ of nurses exhibit their knowledge that suctioning must be performed whenever required, whereas the other researcher identified that $66,7 \%$ of ICU nurses have good about the frequency of the suctioning procedure (Majeed, H. M. (2017).

$19.7 \%$ (21) nurses knew that the negative suction pressure of less than $150 \mathrm{mmHg}$ is used for effective suctioning and this needs to be checked by occluding the end of the suction tube. On contrary more than $70 \%$ of nurses knew the correction suction pressure that has to be applied, but are not practically applying it (Maraş, G. B., Eşer, I., Şenoğlu, N., Yılmaz, N. Ö., \& Derici, Y. K. (2020).

More than $50 \%$ of nurses in the current study knew that the best position for non-contraindicated patients is semi fowler's position, the suction procedure has to be performed based on audible secretion sound and a maximum of 2-3 passes can be done if patient tolerates the procedure which is in align with other studies (Maraş, G. B., Eşer, i., Şenoğlu, N., Yılmaz, N. Ö., \& Derici, Y. K. (2020).

\section{ATTITUDE ASSESSMENT}

On contrary to the mean knowledge score (low), 68.466\% (average) is the score of attitudes of nurses towards suctioning. Many studies revealed that the nurses have good score in practice compared to knowledge score and 


\section{ARTICLES}

in one study it shows $80.37 \%$ (Zeb, A., Ali, F., Hussain, N., Shah, S. H. A., \& Faisal, S. (2017). Many of the nurses are aware that vacuum regulator must set less than $150 \mathrm{mmHg}$, but unable to identify the correct range in the knowledge assessment.

The two items in the attitude questionnaire pointed out towards the lack of evidence-based practice among the study participants ((Mwakanyanga, E. T., Masika, G. M., \& Tarimo, E. A. (2018), which includes pain medication are not at all required before suctioning and $49.2 \%$ accepts that not to instill $0.9 \%$ sodium chloride solution into the artificial airway before suctioning which is in par with another study (Majeed, H. M. (2017).As mentioned in the table above, most nurses responded correctly with attitude questionnaire, which is well supported by the literature (Majeed, H. M. (2017) \% (Zeb, A., Ali, F., Hussain, N., Shah, S. H. A., \& Faisal, S. (2017).

Relationship between knowledge and attitude on practice of artificial airway suctioning

The mean score of knowledge and attitude questionnaire is $47.5 \%$ and $68.5 \%$ respectively and shows mild correlation between knowledge and attitude (Table 5).

The study group comprises 42 samples with critical care experience and 80 samples are with experience in medical- surgical wards, endoscopy, and dialysis. Surprisingly only 5 samples were having high knowledge score (50\%-75\%) and 3 of them are working in critical care units. Moreover, they have experience related to artificial airway suctioning during their staff and student period and have undergone training related to suctioning. Regarding attitude score, 36 participants were having high score and 10 of them were having experience in critical area. Only 2 participants were having low practice score and majority of them having average attitude score.84 participants have undergone training session related to artificial airway suctioning. In a study conducted in India, depicts that $78 \%$ did not attend any training program and have acceptable level of knowledge and some inadequacies in practice (Varghese, S. T., \& Moly, K. T. (2016).

Association between knowledge, attitude and selected demographic variables

Statistically significant association is determined with the area of experience and knowledge score and the training session undergone with the practice score (Table 3\&4). Our current study is in line with other researcher's statement that there are no significant association in nurse's knowledge and attitude except the training undergone and ICU experience (Majeed, H. M. (2017). Another study depicts most of the nurses (80.6\%) were having undesirable knowledge level and ICU trained nurses exhibits significant knowledge level. With increase in the years of experience in ICU, the nurses demonstrate evidenced based practices in suctioning procedure, which is lacking in the present study Chen, W., Hu, S., Liu, X., Wang, N., Zhao, J., Liu, P., ... \& Hu, J. (2021).

\section{CONCLUSION:}

The research study brought an insight regarding the knowledge and attitude among graduate (B.Sc. Nursing) nurses. It is very important to identify the factors that contribute with the findings of the study. The current study revealed that knowledge level is less than average whereas they demonstrate above average attitude score towards practice.

\section{RECOMMENDATIONS:}

- The study can be replicated on larger sample with intervention to determine statistical significance.

- The nurses should utilize the available resources to update their knowledge by reviewing the evidencebased practices related to suctioning and attend seminars and workshops.

- As the basement of nursing career is the nursing education that nursing students receive, should be well nourished by inculcating the EBP in theory and clinical practice. 


\section{ARTICLES}

\section{REFERENCES:}

1. Credland, N. (2016). How to perform open tracheal suction via an endotracheal tube. Nursing standard (Royal College of Nursing (Great Britain): 1987), 30(35), 36-38.

2. Maraş, G. B., Eşer, I., Şenoğlu, N., Yılmaz, N. Ö., \& Derici, Y. K. (2020). Increasing suction pressure during endotracheal suctioning increases the volume of suctioned secretions, but not procedure-related complications: a comparative study in open system endotracheal suctioning. Intensive and Critical Care Nursing, 61, 102928.

3. Mwakanyanga, E. T., Masika, G. M., \& Tarimo, E. A. (2018). Intensive care nurses' knowledge and practice on endotracheal suctioning of the intubated patient: A quantitative cross-sectional observational study. PloS one, 13(8), e0201743.

4. Majeed, H. M. (2017). Assessment of knowledge and practices of intensive care unit nurses about endotracheal suctioning for adult patients in Baghdad teaching hospitals, Iraq. Int J Res Med Sci, 5, 4.

5. Pashaeypoor, S., Ashktorab, T., Rassouli, M., \& ALAVI_MAJD, H. A. M. I. D. (2017). Experiences of nursing students of evidence-based practice education according to rogers' diffusion of innovation model: a directed content analysis. Journal of Advances in Medical Education \& Professionalism, 5(4), 203.

6. Rubin, S. J., Saunders, S. S., Kuperstock, J., Gadaleta, D., Burke, P. A., Grillone, G., ... \& Platt, M. P. (2020). Quality improvement in tracheostomy care: A multidisciplinary approach to standardizing tracheostomy care to reduce complications. American journal of otolaryngology, 41(2), 102376.

7. Zeb, A., Ali, F., Hussain, N., Shah, S. H. A., \& Faisal, S. (2017). Knowledge and practice of ICU nurses regarding endotracheal suctioning in tertiary care hospitals, Peshawar. JOJ Nurse Health Care, 2(4), 55 